\title{
Bi-linear 復元力特性を持つ構造物の地震応答*
}

\author{
EARTHQUAKE RESPONSE OF STRUCTURES HAVING \\ BI-LINEAR RESTORING FORCE CHARACTERISTICS
}

\section{1. ま え がき}

本研究は線型限界と bi-linear 復元力特性とに注目し て, 1 質点系の非線型振動の地震応答を求め, この絶対 最大量を線型振動時の周期のもとにプロットすることに より（以後これを非線型振動地震応答スペクトルと呼ぶ こととする）従来用いられてきた地震応答スペクトルと 比較検討したものである。

構造物の耐震設計においては地震の強さの頻度と構造 物の損傷とを結びつけて対応させることが必要であり, このためには線型振動とともに非線型振動の応答量が考 虑されねばならない。すなわち降伏点に注目した復元力 の弾塑性に基づく非線型振動は地震の強さの頻度を構造 物の損傷の程度に結びつけることを川能にして，これを 許容し得る構造物の損傷にそ，ていくつかの段階に設定 すれば弾性計算のみで生じる過大な震度を減ずる可能性 も期待できる ${ }^{1)}$ 。

一方コンリート構造物のごとく，応力ーひずみ関係 が非線型を示す材料特性に基づく非線型性，あるいはひ び割れのごとく降伏点以下での復元力特性の非線型性は 弾性振動範囲内での減衰的効果の要因の 1 つして上記 の弾望性振動とは異なった意味で扱うことができる。

どちらかというと個々の構造物を対象とした復元力特 性の把握に関する研究 ${ }^{2)}$ ， 応答計算方法についての研 究 $^{5) ~ 8) ~}$ 等とは別に, 地震応答スペクトルを用いて非線型 振動応答特性を把握しようとする研究 ${ }^{92 ~ 13) ~}$ 数多く, こ の方法によれば，幾種かの非線型特性について周期をも とにした応答特性を得ることができる。非線型振動では 各次のモードに相応する応答を重ね合わせることはでき ないので応答スペクトルから応答量を算定するには更に 多くの検討を必要とするが ${ }^{12)}, 1$ 質点系としての応答が

*士木学会第 25 回年次学術講演会にて一蔀発表

** 学生会員 工修 東京都立大学大学院博士課程

国 井 隆 弘**
By Takahiro Kunii

支配的である場合が多いことから，応答スペクトルによ って非線型応答特性を解析することは妥当と思われる。

非線型振動の応答スペクトルを扱う場合, 多くの研究 は復元力特性に扔ける線型限界の設定, あるいは線型限 界と最大変位との相互関係に注目している。Bycroft $ら^{9)}$, Response Analyzer Committe ${ }^{10)}$ は加速度が各周 期にわたって一定であるような線型限界を設定している が，この場合，比較的長い周期の応答が求めにくい。 Veletsos と Newmark ${ }^{11}$ は完全塑性型について線型応 答変位をひき下げる方法で, すなわち地震波を拡大する 方法を用いると同時に一方では ductility factor に基づ いて整理している。本研究のごとく bi-linear の特性に 注目する場合, 非線型振動における安全度の問題より, どちらかといえば非線型応答の特性の把握に重点が置か れることから本研究では線型振動の応答量を基準とした 線型限界を用いている。

非線型復元力特性として多くの研究は完全塑性型を導 入しているが，久田ら ${ }^{4)}$ は bi-linear 特性についてその 最も線型に近いものから完全塑性型まで変化させて応答 量に与える効果を調べている。本研究では更に発展さ せ, 周期, 線型限界, bi-linear 特性, 線型応答量等の 各パラメーター相互間での応答量の関連性を解析した。

以上の考察のもとに, Taft と El-Centro の地震加 速度を用いて解析した結果, 応答量は線型限界のみなら ず, 周期, 線型応答量, bi-linear 特性等とも相互に関 連し合って影響を受け, 非線型振動の応答量が線型振動 を上まわる場合も認められた。なお, 曲げ振動系の多質 点系の応答と, これら 1 質点系との関係, および粘性減 衰が非線型応答スペクトルに及ぼす影響について若干検 討してあるが問題点を指摘するにとどめた。

\section{2. 解 析 方 法}

線型限界は構造物に固有のものであり, まえがきで述 
ベたごとく非線型振動のもつ効果のねらい方によっても 異なる。構造物の破損の程度に注目する場合には, 降伏 応力を越えた挙動が問題となり, 弾性範囲内での非線型 性を問題とする場合には比較的低い応力での応答量に注 目されると考えられる。小林 ${ }^{1}$ は大中小の三段階の地震 を考え，それぞれに対して異なった復元力特性を適応さ せて興味ある結果を得ている。

応答スペクトルの形で非線型振動を扱う場合, より一 般的な応答傾向を得るとき，あるいは設計に直接結びっ く実践的な量的解析を行なら際, そのメリットは倍加さ れる。この意味で周期にかかわりなく一定な加速度を線 型限界として解析した Bycroft らの研究》 は実践的に 有効な線型限界を選んだものと理解される。しかしなが

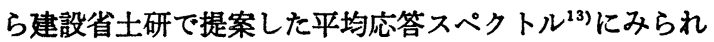
るごとく, 応答加速度は一般に周期が 1 秒の付近から周 期の増加とともに一定して減少する傾向を示す。このた め比較的大きい変位を持つような長い周期に対して線型 限界をとり決めるのが困難であり，文献 9，10）はと もに周期 1 秒付近より短い籁囲を扱っている。

ductility factor は復元力特性の描くヒステリシスル 一プのもつエネルギー的特性とも関連づけられ, 耐震安 全性の尺度として構造物の終局状態に対する基準を追求 するものとして ${ }^{14)}$ 弾塑性応答解析に多く用いられてき た。しかしながら，この場合，完全塑性型復元力特性と 結びつけられることが多く, bi-linear の特性との関連 性において, その意義は筆者の知る限りあまり検討され ていないようである。

本研究は非線型振動応答のもつ減衰的効果を応答スペ クトルの中で把握しようとするもので, この目的からす れば, 線型限界を耐震安全性からあるいは応答加速度か ら設定するのは得策ではなく, 応答量は変位を用いて検 討するのがわかりやすい。本研究では以上の考察のもと に, 線型振動の応答変位に注目した。すなわち線型応答 変位をそれぞれの周期で同じ割合でひき下げてそれを線 型限界とした。この方法は線型応答変位を線型限界とし たとき, 更に拡大された地震波に対する非線型応答を求 めることと同じ意味を持つことはいうまでもない。いま 線型応答スペクトルの変位を $x_{e}$ とすれば, 線型限界 $x_{y}$ は $x_{y}=n \cdot x_{e}$ となる。ここでは $n$ は 0.1 から 1.0 ま で 0.1 きざみで与えられるパラメーターとする。この とき用いられた地震波は最大加速度を $200 \mathrm{gal}$ とした Taft, Calif. $1952 \mathrm{~N} 21^{\circ} \mathrm{W}$ および El-Centro, Calif. 1940 NS の二種である (両地震波とも, 最初の 20 秒間 の波形が入力波とされた)。

復元力の非線型が線型に近いような bi-linear 特性で あるとき，ヒステリシスの描く面積に相応したエネルギ 一吸収はあまり期待できないと考えられ，むしろ非線型
笔囲に入ったときの固有周期の変化に伴う共振的現象に 対する効果が注目されるが，久田ら゙)は力一変位関倸の 中で弹性籁囲内に対する塑性筈囲内のばね定数の比を -0.2 から 1.0 まで変化させて，その間の応答量の変 動を解析した。本研究ではこの比の值 $A$ を $A=0.1 \sim$ 1.0 と 0.1 きざみとして(ただし復元力特性は後述の ごとく無次元化されたものを扱っている) $A$ の変化に伴 ら応答量を線型限界のパラメーター $n$ と結びつけて解析 している。

\section{3. 応答計算法}

さきに筆者は曲げ振動系の 多質点系における応答計算方 法を提案したが7),8)，これを 1 質点系に適応させ，更に無 次元的に扱えばディジタル的 な応答計算手段として比較的 簢単な方程式が導かれる。 図一1に示した振動系の運動 方程式は

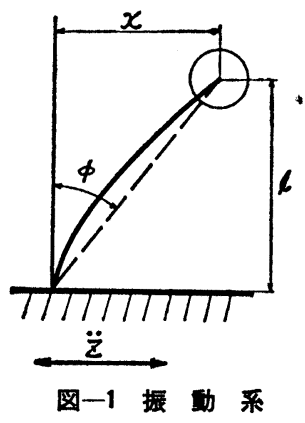

$m \ddot{x}+P=-m \ddot{z}$

ただし， $m:$ 質点の質量

$x$ : 翼点の基盤に対する相対変位

$P:$ 質点に作用する復元力

$\ddot{z}$ : 地震加速度

更に図一2に示された曲げモーメント $(M)$ と回転角 ( $\phi$ ）の復元力特性から， $p$ を円振動数として次式が得ら れる。

曲げモーメント

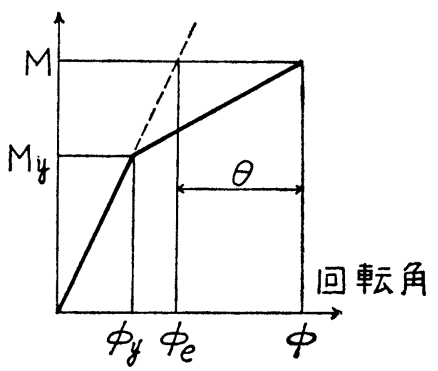

図一2 復元力特性

$$
\begin{aligned}
& x=\phi l \\
& \phi=\phi_{e}+\theta \\
& P=m p^{2} \phi l
\end{aligned}
$$

ここに, $\phi_{\boldsymbol{e}}$ : 回転角 $\phi$ の線型的な部分で復元力に関俰 する

$\theta:$ 回転角 $\phi$ の非線型による増加部分で復元 力に関係しない 
式（2）を式（1）に代入すれば

$$
\ddot{\phi}_{c}+p^{2} \phi_{c}=-\ddot{z} / l-\ddot{\theta} \text {. }
$$

が得られるが，式（3）は右辺に強制力項として った運動方程式であり， $\theta$ は試算的に求める方法がとら れる。式 (3) の両辺を $\phi_{y}$ で割れば無次元量としての 方程式が得られる。

$$
\left.\begin{array}{l}
\ddot{\phi}_{c}+p^{2} \phi_{c}=-\ddot{\bar{z}}-\ddot{\ddot{\theta}} \\
\phi_{c}=\phi_{c} / \phi_{y_{i}} \bar{\theta}=\theta / \phi_{y}, \quad \bar{z}=z / x_{y}
\end{array}\right\}
$$

式 (4) に相応寸る復元力特性が 図一3に示される が,この関係は曲げ振動系においてのみ有効性を持つの ではなく，せん断系に用いられる力一变位関係も同様に

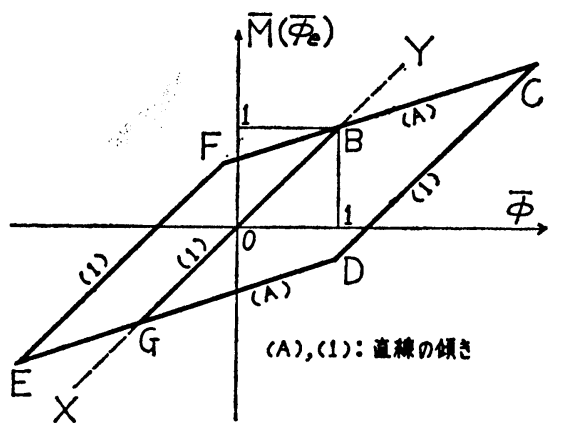

因一3 無次元化された得元力特性 $(A=1 / 3)$

この関係で扱うことができる。図一3 は縌軸に $\bar{M}(=$ $\left.M / M_{y}\right)$ あるいは $\phi_{e}$, 横軸に $\phi$ をとってあるが, 線型 螌囲すなわち $\mathrm{GB}, \mathrm{CD}, \mathrm{EF}$ は直線の傾きが 1 となり, 非線型範囲 $\mathrm{FC}, \mathrm{DE}$ は傾きが $A(0<A \leq 1)$ で示され る。 $\bar{\theta}$ は任意の線分上から $\bar{\phi}$ 軸に平行に引いた直線が 線分 $X Y$ と交わるまでの長さで与えられるが, 復元力 特性の各位置に対して次の関係を持っている。

i） FC 上 (非線型範囲)

$$
\bar{M}=\bar{\phi}-(1-A)(\bar{\phi}-1), \bar{\theta}=(1-A)\left(\bar{\phi}_{\ell}-1\right) / A
$$

ii) $\mathrm{CD}$ 上 (線型範囲) $\bar{M}=\bar{\phi}-(1-A)\left(\bar{\phi}_{c}-1\right), \bar{\theta}=(1-A)\left(\bar{\phi}_{e} c-1\right) / A$

iii) $\mathrm{DE}$ 上 (非線型範囲)

$\bar{M}=\bar{\phi}-(1-A)(\bar{\phi}+1), \bar{\theta}=(1-A)\left(\bar{\phi}_{\boldsymbol{e}}+1\right) / A$

iv) $\mathrm{EF}$ 上 (線型範囲)

$\bar{M}=\bar{\phi}-(1-A)\left(\bar{\phi}_{F}-1\right), \bar{\theta}=(1-A)\left(\bar{\phi}_{e F}-1\right) / A$

\section{4. 応答 特 性}

\section{（1）変 位}

Taft および El-Centro の地震波について, 周期が 0.1 秒から 10 秒まで比較的細かくプロットして（98 個）描いた非減衰の線型変位応答スペクトルが図一4 と 図一5 にそれぞれ示してある。非減衰振動のため周期が

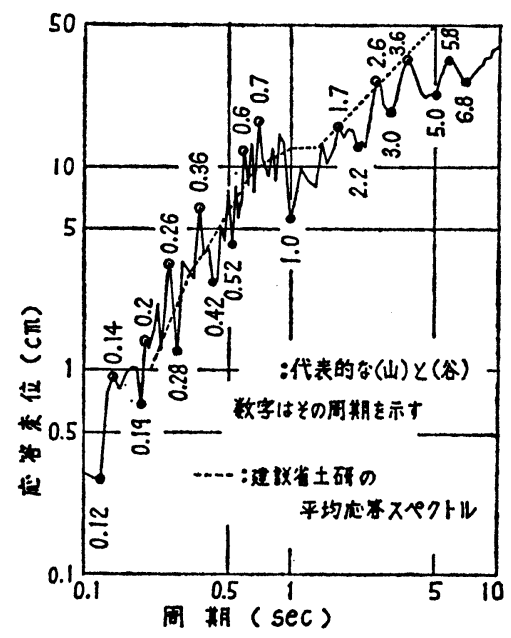

图一4 線型変位応答スペクトル (TAFT)

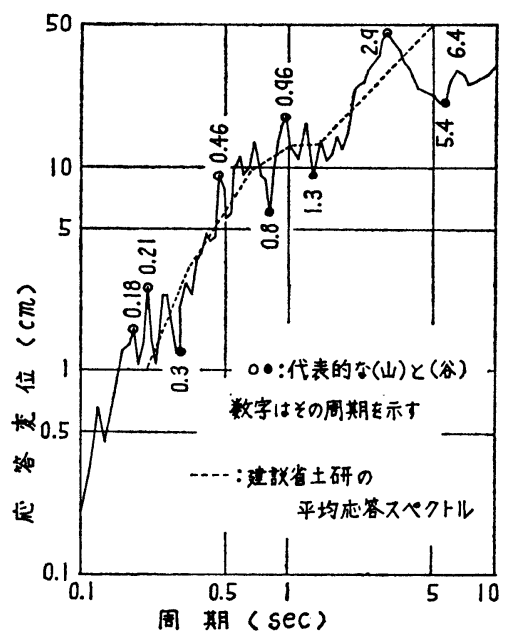

図一5 線型变位応答スペクトル（EL-CENTRO）

3 秒付近以下では特に複雑な形状を呈しており，このま まの形で検討していくのは適当でない。そこで応答スペ クトルの概形を得る方法として次に述べる手段が選ばれ た。

まず各応答スペクトルの中心線を想定するとともに， 平均応答スペクトルに注目して，これらを大きく上まわ る応答量を示す代表的な（山）の部分, およびその逆の （谷）の部分をいくつか選び出し，これに相当する周期 が入力地震波に対して敏感にあるいは鈍感に反応を示し たと考え, 応答スペクトルの概形の特徴を与えるものと した。次に応答スペクトルの全体的な概形を与えるもの として 0.1 秒から 10 秒まで対数目盛でなるべく等間隔 に約 25 個の周期を選んだ。このようにして描かれた応 答スペクトルが 図一6, 図一7 の $n=1.0, h=0.0$ の曲 線で示される。

bi-linear 復元力特性を持つ振動系においては線型振 


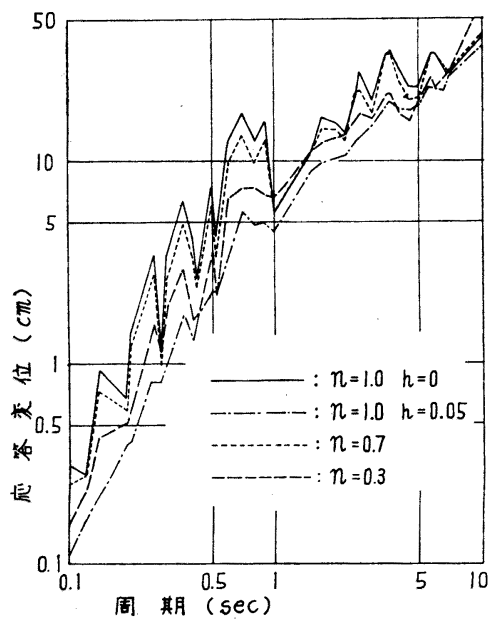

図一6 非線型変位応答スペクトル (TAFT, $A=0.3$ )

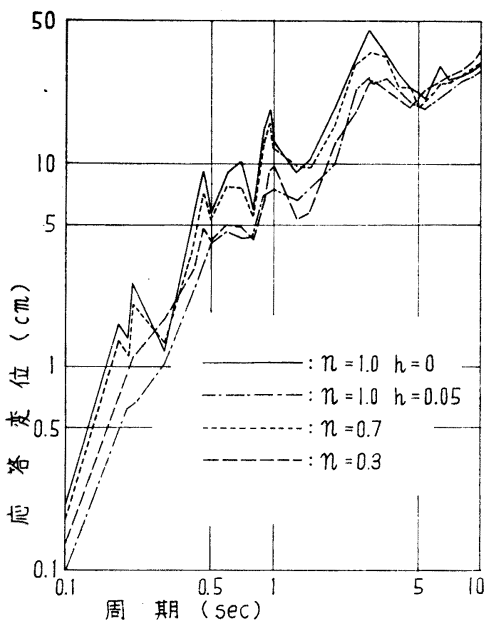

図一7非線型変位応答スペクトル

(EL-CENTRO, $A=0.3$ )

動状態から非線型状態に移行するとともに，系の持つ固 有周期が明らかに変化すると考えられるため, 系が共振 状態を生じるような入力を受けたときには（図一4, 図一 5 でみられた（山）の部分はこの共振的な部分とも考元 られる) 線型振動にみられる共振は生じにくいことも予 想がつく。図一6, 図一7 は $A=0.3$ のとき $n=1.0$ (線 型）について粘性減衰定数 $h$ が 0.0 と 0.05 の場合に ついて $n=0.7$ と $n=0.3$ と比較したものだが, 非線型 応答が（山）で線型応答を大きく下まわり，逆に（谷） では線型応答に近い值を示寸かあるいは上まわることが 観察される。図一8 (a)，(b) はこの性質を更にわかりや すく説明したもので, 線型限界を示す $n$ の值にかかわり なく（山）と(谷) では対照的に異なる非線型的効果を もつことが理解される。このため結果として（山）と

（谷）が解消されて, 応答スペクトルは平坦化される傾

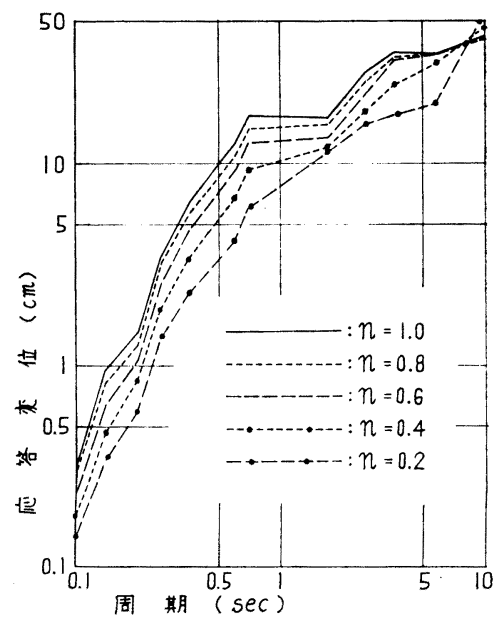

(a) (山) の応答

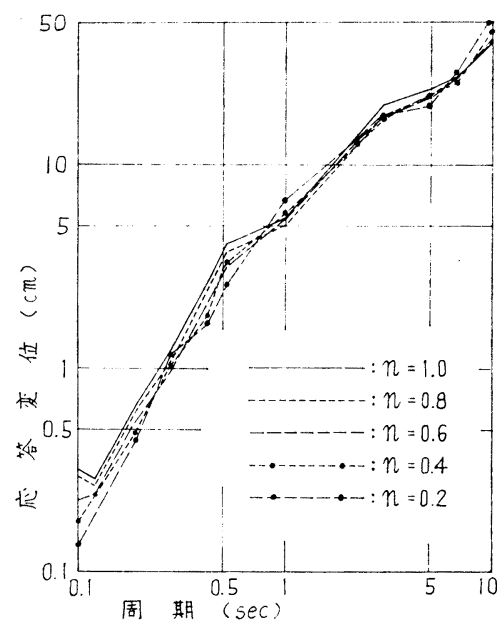

(b) (谷) の応答

図一8 非線型変位応答スペクトル (TAFT, $A=0.5$ )

向をもち, 非線型応答が粘性減衰を持つ線型応答と比較 的相似したスペクトル形を示すことがうかがわれる。

図一9，図一10 は線型限界が応答におよぼす影響を， 線型に近い場合 $(A=0.8)$ と完全塑性型に近い場合 $(A$ $=0.2 ） の 二$ 種類について, 代表的な周期を用いて明ら かにしたものであるが，応答量の增減は線型応答変位に 対する非線型応答变位の比 $R\left(R=x / x_{e}\right)$ で説明されて いる。ここで選ばれた周期は 図一4，図一5 で（山）に

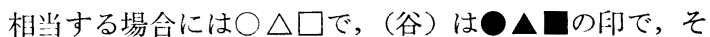
の他は無印で区別されており（図内の数字は周期を表わ す）周期の長短，および共振性において代表的なものと した。

全体的にみて周期が長くなるに従って応答比 $R$ は大 きくなる性質があり， $A=0.8$ のときには $n$ が 0.5 よ り小さい場合, 周期が 2 秒付近より長いものに対して特 


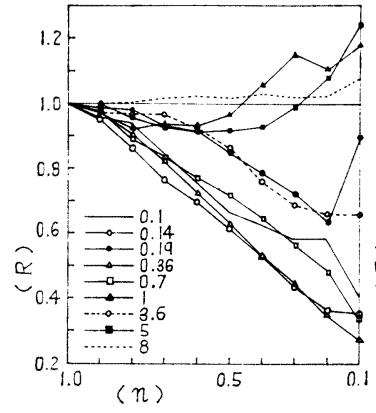

(a) $A=0.8$

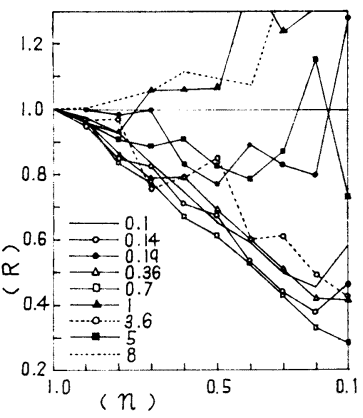

(b) $A=0.2$ 図一9ｎをパラメーターとした応答変位 $($ TAFT $)$

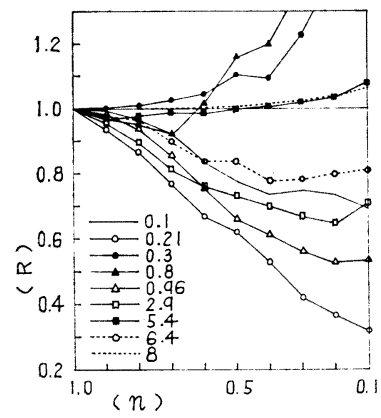

(a) $\quad A=0.8$

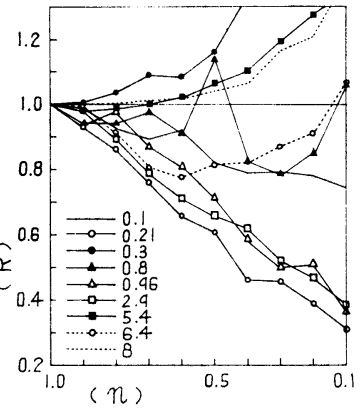

(b) $\boldsymbol{A}=0.2$
図一10nをパラメーターとした応答変位（EL-CENTRO）

にこの傾向を示す。これは比較的長い周期において非線 型振動による応答量の低下が少ないことを示すもので， 傾向としてはVeletsos らの研究 ${ }^{11)}$ と同じであるが, (谷) にあたる周期においてはこの傾向はあてはまらず, むしろ $n$ の值に大きく影響を受けている。一方（山）の 場合は $n$ の值が小さくなるほど, 図上で直線的に小さい $R$ の值を示す傾向を持つが，周期が比較的長いものは $n$ の減少に対して $R$ の低下の割合が小さくなる。

（山）と（谷）のもつ応答特性は $n$ の值についても明 らかな相違を示す。一般には $n$ の減少に伴って両者の $R$ の值の差は大きくなるが,この差は比較的短い周期のと
ころで特に大きい。また（谷）にあたる部分は $n$ の変化 に伴，て変動の大きい $R$ の值をとっているが，この傾 向は $A$ が 0.8 よりも 0.2 のときの方が強いようであ る。

この $A$ に対する特徴を更にくわしく調べるため 図一 11, 図一12 では $n=0.5$ のときの $A$ をパラメーターに した応答量を描いているが，(山）の周期は $A$ が 0.8 以 下ではほぼ同じ $R$ の值を持つ傾向にあり，この結果に 限れば久田らの研究 ${ }^{4)}$ と同様であるが，ここでも(谷) にあたる周期の応答が $A$ の変化に対して大きな変動を示 している。

図一13 は線型振動において粘性減衰をもつ応答が減 衰定数 $h$ をパラメーターにして描かれたものだが，共振 状況を示すと思われる（山）の応答が（谷）の応答に比 ベて減少度が大きいこと，長い周期を持つ系の応答ほど 減少度が小さくなること等について考えれば，非線型応 答の場合に相似しており，図一6，図一7 でみられた平 坦化現象からくる相似性が裏づけられる。

図一14 (a)〜 (f) は $A$ と $n$ を同時にパラメーターと して代表的特性をもつ周期について $R$ をプロットした ものだが，(a）は短い周期の（谷）に相当するし，(b) は同じく（山）に相当し，(c) は中間的な周期の（谷） の場合，(d)，(e) は比較的長い周期の（谷）と（山）, (f) は相当長い周期の場合である。（山）の場合は $A, n$ の変化に対して $R$ の変動が一般に少なく, $R$ 值の作り 出す面が多くの場合平らである。短い周期は（b）で代 表され，周期が長くなるに従って（e）のような形に変 化していくが，その変化の傾向は図一9～図一12 でみら れたものと同じである。(谷) の $R$ の面は複雑であるこ とが多く，しかも周期ごとに独特の形を示すため周期の 長短に関しては一般的な特徴がつかめない。しかしなが ら，大体 $R$ 值は 1 に近い值をとり，このことは線型応 答と同じ応答量を持つ傾向があることを示しているが， 線型応答を上まわる $R>1$ を示す場合は $n$ が 0.5 よ り小さい時かあるいは $A$ が 0.3 より小さい時に限られ

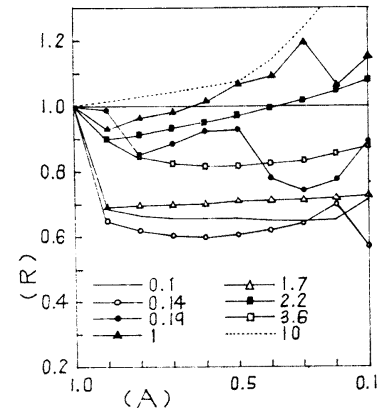

図一11Aをパラメーターとし た応答変位（TAFT， $n=0.5$ )

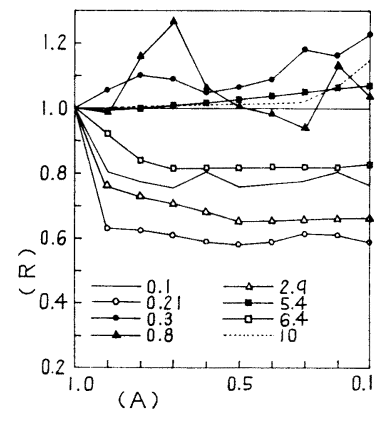

図一12A をパラメーターとし た応答変位 (EL-CENTRO, $n=0.5$ )

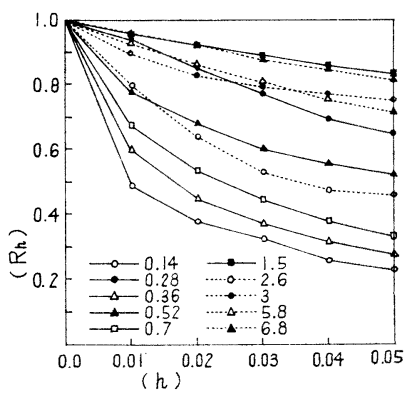

図一13 線型減衰応答 (TAFT) 


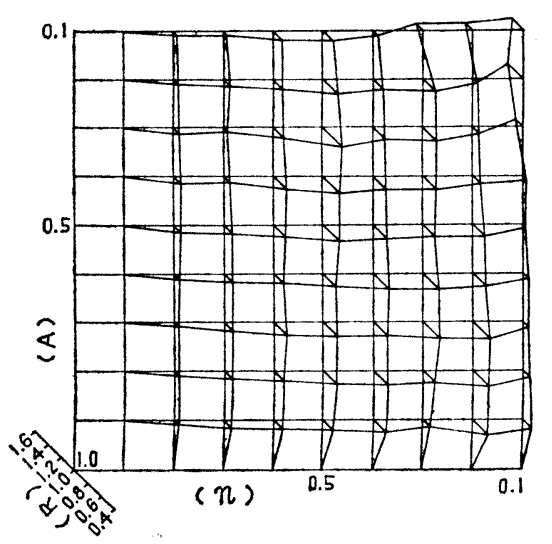

(a) $T=0.12$

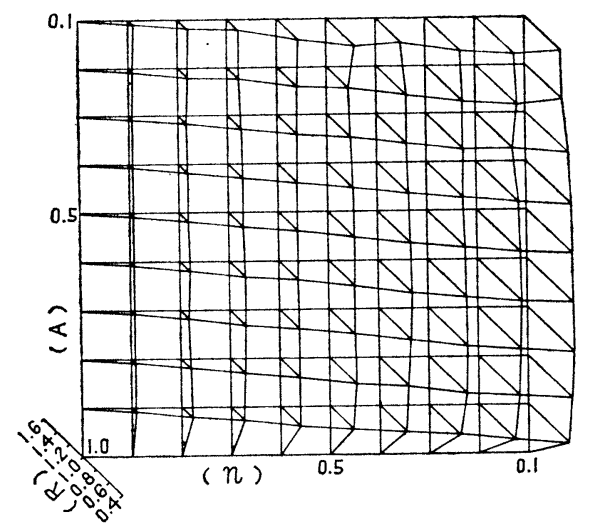

(b) $T=0.14$

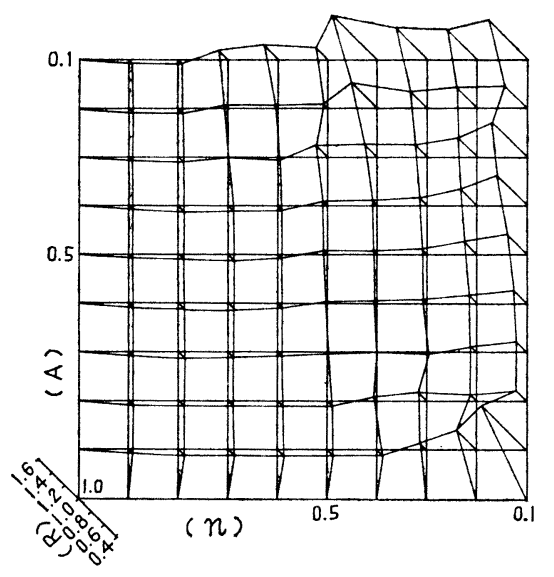

(c) $T=1.0$

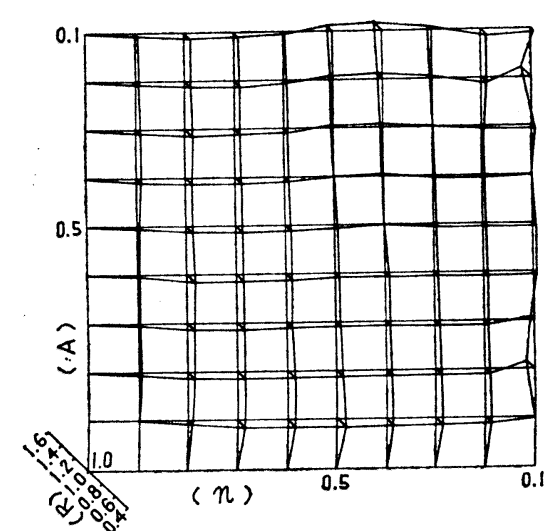

(d) $T=2.2$

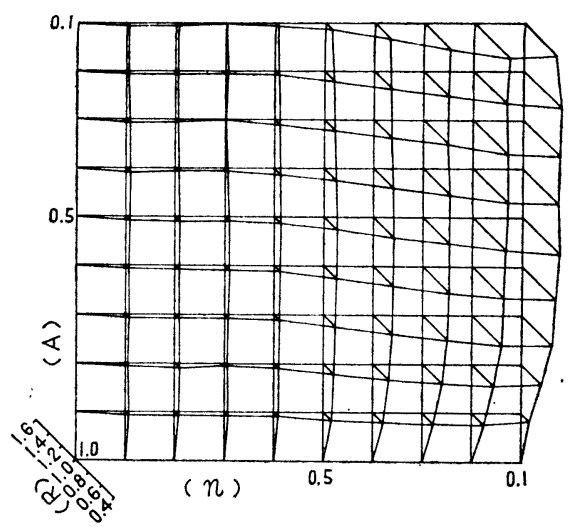

(e) $T=3.6$

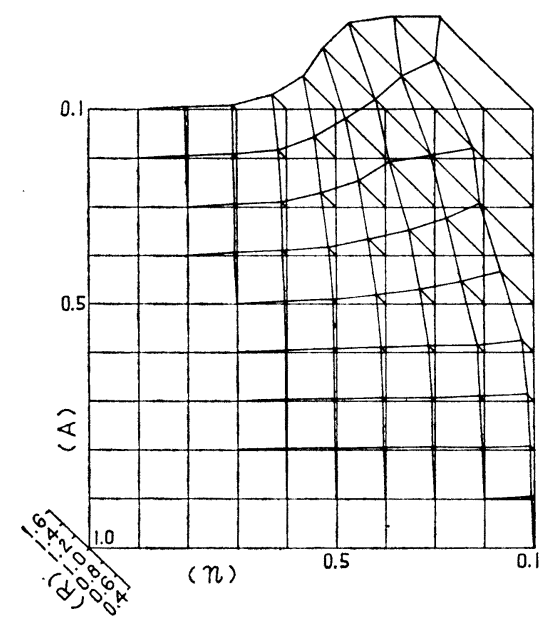

(f) $T=10.0$

図一14 $A$ と $n$ をパラメーターとした応管変位 (TAFT)

るようである $((\mathbf{a}),(\mathbf{c}),(\mathbf{d})$ 参照)。

周期が 7〜10 秒の間では本研究に用いられた二種の地 震波は応答スペクトルの中でピークを持たないため,こ れまでのごとく（山）と（谷）にわけて解析できない が，その特徴は例外なく（f）と同形の $R$ の面をもつ。 $n$ と $A$ がともに小さくなるほど $R$ の值は 1 を大きく うわまわり, その他の場合は $R \doteqdot 1$ となって周期が 7 秒 以下のこれまでの特性とは傾向が全く異なる。 


\section{（2）粘性隇衰の影鳤}

これまでの解析は非線型振動のもつ減衰的勃果に主眼 が直かれたため非減衰振動が扱われてきた。しかしなが ら, 実祭の構造物には何らかの形で減衰作用が働くはず であり, 非線型応答における解析もこの作用を考慮した 上で行なわれるのが理想的である。非線型振動の中で粘 性減衰作用がどのように影響するのか, そしてまた，減 衰の原因と考えられているものの中で非線型振動の減衰 的効果がどの程度の割合で含まれているものなのか等を 明らかにしていくことは興味のあることであり，筆者の 期待するところだが，本研究では粘性減衰が作用する場 合としない場合とについて非線型応答を比較することか ら，その一般的な傾向を簡易につかみとるにとどめた。

图-15 では（a）減衰定数 $h=0$, （b） $h=0.02$ の場 合について $n$ と $R$ の関係を求めたものだが,一般的な 特徴として粘性減衰が作用すると, 非線型振動は非減衰

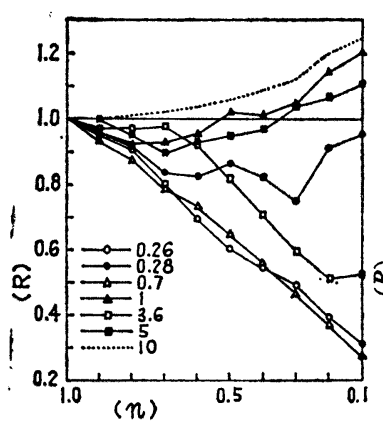

(a) $h=0.0$

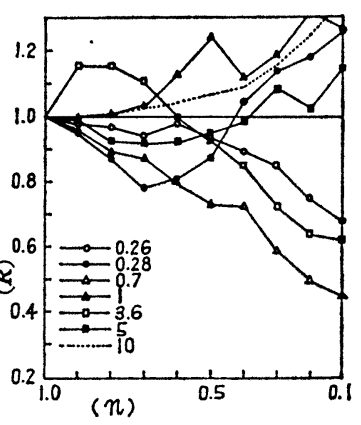

(b) $h=0.02$
図一15 粘性娍表の作用した応答変位 (TAFT, $A=0.6$ )

振動のときよりも応答量の減少度合を少なくする。減衰 が作用した場合, 応答が非線型振動から受ける効果が弱 まることは予想されることだが, $h=0$ で $R$ が 1 よりも 大きい值をとっていた周期 $(0.28,1.0,5.0,10.0)$ が $h=0.02$ では更に $R$ の值を大きくしていることは注目 される。なお, $n$ の変化に伴う応答比 $R$ の変動は周期 が 3.6 秒の場合のように極端にその傾向を変えてしまう ものが他にもいくつか見られたが，多くの場合その形の 特徴は粘性減衰によって大きく変わらないようである。

\section{(3) 加 速 度}

応答加速度は構造物の応答問題において実践的には最 も注目されるものであり, 非線型振動の諸特性が応答加 速度を通して検討されれば都合がよい。しかしながら， 非線型振動においては線型振動の場合と違って応答量の 大小と入力加速度の増减, すなわち許容される加速度と を直接結びつけることはできない。一般に非線型応答は 線型限界を持った復元力特性に基づいて考えられるもの
であり，そのため振動系のもつ周期が線型振動の周期よ り多くの場合長くなる傾向にある。したがって, 同し応 答変位を示す場合には線型振動の応答加速度の方が大き いことになり，このことは復元力特性において線型限界 を越えたところでは，わずかな応力の増加でも急激に変 位が増加する性質 (bi-linear) からも想像できる。

非線型応答における応答加速度は線型限界と応答変位 に大きく依存し，またこれらに注目しながら解析されね ばならないことはいらまでもなく，いわゆる弾塑性振動 として構造物の安全度の観点から検討されるのが適当で あろら。小堀 ${ }^{14)}$ は降伏変位と終局変位とから終局安全率 を求めており，またVeletsos らの研究 ${ }^{11}$ は弾塑性応答 の解析の中で ductility factor を崩壊を基準とした安全 度の尺度としている。

本研究は非線型応答について bi-linear 復元力特性と 線型限界とをパラメーターとして，その相互間の特性を 調べようとするもので, この目的からすれば応答加速度 を用いて検討するのは得策でない。なぜならパラメータ 一の $A$ と $n$ が小さくなればそれだけ応答加速度が小さ くなることが前もって予想され，パラメーターによる応 答特性がつかめないからである。図一16 に示されるご とく, 応答加速度は明らかに $n$ に大きく支配され, $h=$ 0.05 の線型 $(n=1)$ の減衰振動が $n=0.3$ の場合を上 まわる值を示し, 応答変位の図 (図一6, 図一7) とは異 なる結果となる。

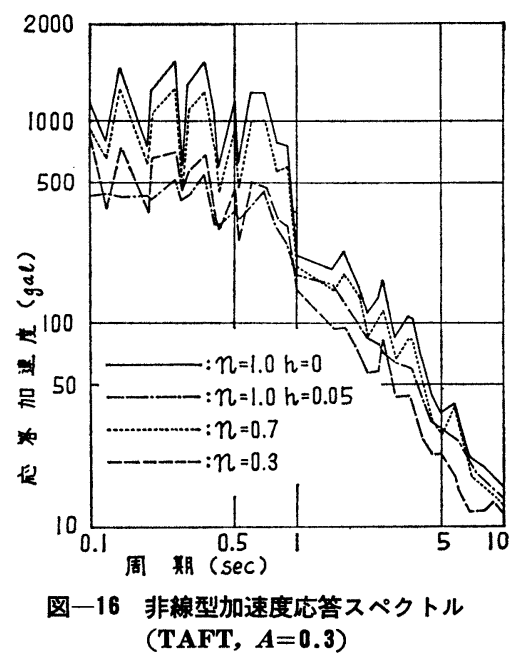

\section{（4）多質点系（曲げ系）の応答}

線型振動の場合, 応答スペクトルの重ね合わせから多 質点系の応答量を算出する方法がとられ得るが, 非線型 振動ではこの手段はとれない。しかしながら，もし系が 1 次振動に大きく支配されるもので, しかも 1 次振動の モードが非線型性から生じるたわみ形と相似するならば 1 質点系としての非線型応答がその系の支配的な傾向を 


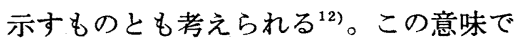
非線型振動から得た応答スペクトルと実 際の多質点系の応答との関係, およびそ れにおよぼす要因を求めていくことは興 味があるが，もし系が曲げに支配される ような振動系であるならば曲げモーメン トが変位に比べて高次振動に支配されや すいという一般的な性質に注目されねば ならない。たとえば断面，剛性が一様な はりのような構造物では, 曲げモーメン トの受ける各次の影響は変位の受ける影 響に比べて振動数比の二乗倍になる。

図一17 はこの様子を 3 質点系につい て示したものだが 1 質点系と比べて応答 曲げモーメントは明らかに相違してお り, 曲げモーメントに非線型特性を依存 している 3 質点系は線型から非線型に移 行するときの曲げモーメントの時間的性 質に，たとえば加速度に支配されるよう な観測ができ，そしてまた非線型特性で
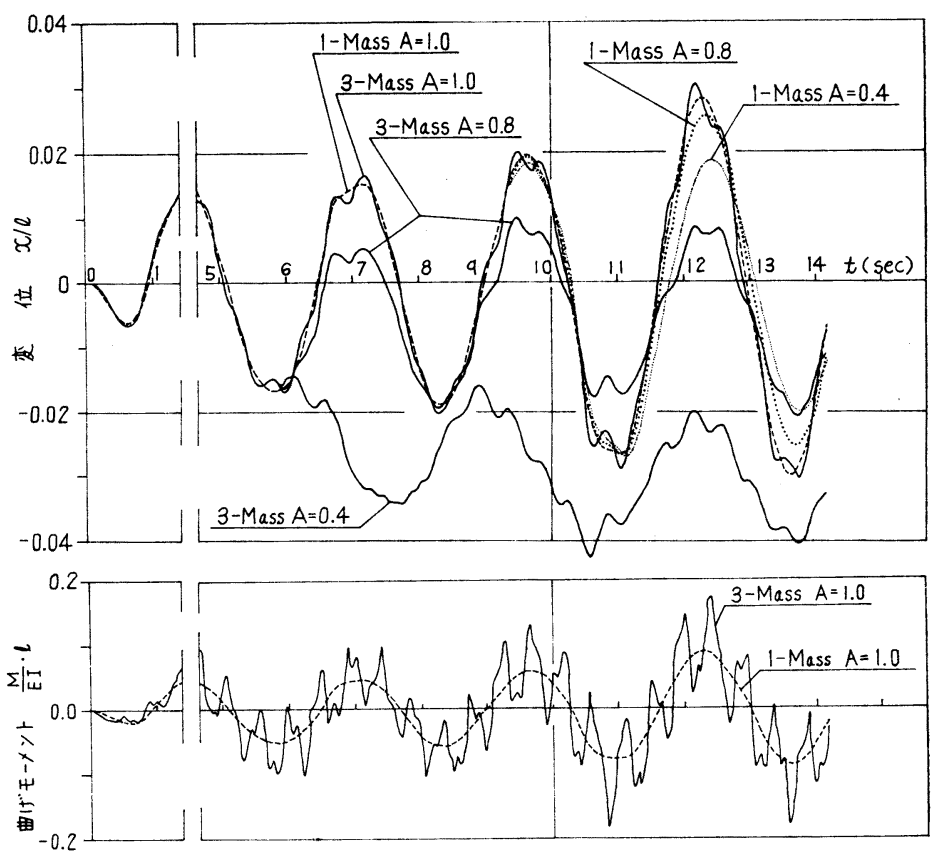

图-17 1 留点系と 3 筫点系の応答 (TAFT, $n=0.5, T=2.6 \mathrm{sec}, l=10 \mathrm{~m}$ ) ある $A$ の值とも同時に無関係でないとも思われる $(A=$ 0.8 と $A=0.4$ では全く異なる応答を示す)。

3 質点系の曲げモーメントは明らかに高次の影響を強 く受けており，それだけ高次の影響が無視できないとと もに，Aの值に敏感に反応しやすい傾向がうかがわれ， 1 質点系の場合とは非線型に入るときの条件が異なるの が明らかである。このため両者の応答変位は相当かけは なれた值を示し, 図一17 の例では 3 質点系が応答変位 の振幅を大きく減少しているにもかかわらず，残留変位 的な要因のためその変位は大きく上まわる $(A=0.4)$ 。

\section{5.むす び}

本研究は bi-linear 復元力特性を表わすパラメーター として $A$, 線型限界のパラメーターとして $n$ を用いて 非線型振動の応答スペクトルを変位で作製することによ り，その傾向を応答比 $R$ で観察したものだが，以下に 記すいくつかの特性が認められた。

（1） 入力地震波として Taft および El-Centro の 二種を最大加速度を $200 \mathrm{gal}$ にして用いたが，両者の示 す非線型応答はほぼ一致した傾向を持つ。

(2) $h=0$ の応答スペクトルは多くの (山) と（谷） を持つが, これらのいくつかに注目して（図一4，5）非 線型応答特性を求めてみると, 減衰的効果は（山）にお いて明らかに大きく（谷）では小さい（図一6 8)。そ してこの傾向は粘性減衰のもつ性質（図一13）と相似す る。

（3）周期の長短からくる応答性質は（2）の傾向に 支配されやすく明確にはつかみがたいが，一般に周期が $0.1 \sim 1.5$ 秒の間では $A$ と $n$ にかかわらず (2) の性 質が強く, $2 \sim 6$ 秒では $A$ と $n$ に敏感に反応して (2) の性質が薄らぐ傾向をもち，7〜10 秒では非線型応答が 線型応答を上まわり $(R>1)$, これは $A$ と $n$ がとも に小さくなるほど顕著である（図一9，10）。

（4）（山）の态答は $n$ が小さくなるほど，Aの值に 関係なく減衰的効果が大きくなるが，しかし周期が 2 秒 より長くなると, この効果は弱まる。一方 (谷) では応 答が $A$ の值に大きく影響され， $n$ の変化に伴う応答比 $R$ の変動は大きく, $A$ が小さくなるほどこの傾向が強い (図一9, 10)。

(5) $A$ の值が 1.0 0.8 の間で $R$ の值は大きく変 化して, 以後 $A$ が $0.7 \sim 0.1$ の間では $R$ の值は一定と なる。しかしながら，(谷) の応答は $A$ の変化に伴って 大きく変動して明確な傾向はつかめない（図一11，12）。

(6) 多くの場合非線型応答は $R<1$ となり線型応 答よりも小さい值を示すが，(谷）の部分および周期が 7 秒より長い場合は線型の応答を上まわり $(R>1), A$ と $n$ が小さくなるほどこの傾向が強い（図一14）。

なお, 粘性減衰が作用する場合 (図一15), 多質点系 との関連性（図一17）について若干記したが，これらに ついては後日発表する機会を得たい。

謝辞 : この研究を進めるにあたり, 終始, 懇切丁寧な ご指導をいただいた奥田秋夫教授に心から感謝の意を表 
わすとともに，惜みない協力をいただいた研究室の皆 様，および電算のプログラミングで協力をいただいた永 田栄造氏（日本ビジネスコンサルタント）に心から感 謝いたします。なお, 計算に東京大学大型電子計算機 HITAC 5020, および都立大学 FACOM 270-20/30 が 用いられた。

\section{参考 献}

1）小林啓美 : 地震の頻度と設计震度, 日本地震工学シンポ ジウム (1962) 講演集.

2）小高昭夫 : 耐震構造の綜合研究, 宇野書店, 上巻, pp. $311 \sim 324$.

3）伯野元彦・四俵正俊：注りの動的破壊時の復元力特性に 関する基礎的実験, 土木学会論文報告集, No. 162, 1969.

4) T. Hisada, K. Nakagawa and M. Izumi : Earthquake Response of Structures Having Various Restoring Force Characteristics, 日本地震工学シンポジウム (1962) 講演集.

5) H.H. Bleich, M.C. Salvadori : Impulsive Motion of Elasto-Plastic Beams, Proc. ASCE, Vol. 79, EM, 1953.

6) Y. Yamada : Elastic-Plastic Analysis of Suspension Bridge Towers Subjected to Earthquake Ground
Motions, Memoirs of the Faculty of Engineering Kyoto Univ., Vol. 23, Part 3, 1961.

7）国井隆弘：曲げ振動系の非線型応答，第 10 回地震工学研 究発表会講演概要, 1969.

8）国井隆弘：非線型振動についての一考察，第 24 回年次学 術講演概要, 1969.

9) G.N. Bycroft, M.J. Murphy and K.J. Brown : Electrical Analog for Earthquake Yield Spectra, Proc. ASCE, Vol. 85, EM 4, 1959.

10) Response Analyzer Committe : Non-linear Response Analyzers and Application to Earthquake Resistant Design, Proc. 2nd WCEE, 1960.

11) A.S. Veletsos, N.M. Newmark : Effect of Inelastic Behavior on the Response of Simple System to Earthquake Motion, Proc. 2 nd WCEE, 1960.

12) R.W. Clough, K.L. Benuska and E.L. Wilson : Inelastic Earthquake Response of Tall Buildings, Proc. 3 rd WCEE, 1967.

13）土木学会，本州四国連絡橋技術調査委員会：本州四国連 絡橋技術調査報告書・耐震設計指針, 1967.

14）小堀鐸二：動的設計の現段階, 日本地震工学シンポジウ 么 (1962) 講演集.

(1970. 10. $14 \cdot$ 受付) 